Review article

\title{
The quality of life of women in puerperium - the introduction of the Mother-Generated Index (MGI) questionnaire
}

\author{
Eva Hendrych Lorenzová ${ }^{1,2}$ *, Sylva Bártlová ${ }^{1}$, Kateřina Ratislavová ${ }^{2}$ \\ ${ }^{1}$ University of South Bohemia in České Budějovice, Faculty of Health and Social Sciences, Institute of Nursing, Midwifery, and Emergency Care, \\ České Budějovice, Czech Republic \\ ${ }^{2}$ University of West Bohemia, Faculty of Health Care Studies, Department of Nursing and Midwifery, Pilsen, Czech Republic
}

\begin{abstract}
The period of puerperium is a critical and transformational period in the life of every woman, newborn and new family on a physical, psychological and social level.

Study design: Descriptive review study.

Goal: The goal of this article is to present the Mother-Generated Index questionnaire, which could be used in the community practice of midwives while nursing women in puerperium.

Methods: We used a content document analysis. The documents were searched for in scientific databases, such as EBSCOhost, Science Direct, Pro Quest, Nursing Ovid, Google Scholar, PubMed or Scopus. The search and the processing of available studies were carried out from February to April 2018. The final selection included eight studies that met the criteria.

Conclusions: The Mother-Generated Index questionnaire resulted as a valid tool which described the subjectively perceived quality of life of women in puerperium and used mixed sets of methods. It is possible to use it in a trans-cultural environment as well. The questionnaire was translated into Czech in 2014, but the research results of its use in women in puerperium are waiting to be published.
\end{abstract}

Keywords: Midwifery; Midwifery Community Care; Mother-Generated Index; Motherhood; Quality of life after childbirth

\section{Introduction}

The birth of a new baby brings great changes in the life of every woman and family. The main task of midwives is to support women's health and the belief that pregnancy and birth are normal and healthy physical processes (Bašková et al., 2011). The WHO claims that midwives are crucial in health support (Grylka-Bäschlin, 2013). The support of a midwife in pregnancy and delivery potentially brings the feeling of well-being in puerperium (Coyle et al., 2001). To make a midwife's care better, a specific tool for the description of the quality of life of women could be used.

The concept of "the quality of life" originates in ancient Rome and Greece and initially it was related to the social and economic aspects of life. The medical database MEDLINE uses the concept primarily in the title of a scientific article in 1975. Currently, there has been an increase in the number of scientific publications regarding this topic, which is proven by the fact that there were only 40 registered works regarding this topic in MEDLINE in 1975, but in 1999 there were more than 12000 and in 2009 more than 138000 (Gurková, 2011). The WHO describes the quality of life as "an individual's perception of their position in life in the context of the culture and value systems in which they live and in relation to their goals, expectations, standards and concerns. It is a broad ranging concept affected in a complex way by the person's physical health, psychological state, personal beliefs, social relationships and their relationship to salient features of their environment" (Baloun and Velemínský, 2018; Vad'urová and Mühlpachr, 2005).

We can approach the concept of the quality of life on two levels - subjective and objective assessment. At present, experts are more inclined to the use of tools for subjective assessment of the quality of life. The subjectively perceived quality of life shows "an individual's perception of their social status regarding their culture and system of values. The final satisfaction depends on their personal goals, expectations and interests" (Vad'urová and Mühlpachr, 2005).

The author of the term salutogenesis, Aaron Antonowsky, criticizes the contemporary health scientific base, which is focused on studying illnesses and their causes rather than the support of health. Salutogenesis deals with active support and understanding of health (Antonowsky, 1996). For this reason, measuring the quality of life of women in puerperium means focusing on salutogenetic results regarding childbirth, which can be useful for prenatal health support. The postpartum

\footnotetext{
* Author for correspondence: Eva Hendrych Lorenzová, University of West Bohemia, Faculty of Health Care Studies, Department of Nursing and Midwifery, Husova 11, 30100 Pilsen, Czech Republic; e-mail: elorenzo@kos.zcu.cz http://doi.org/10.32725/kont.2019.016
}

Submitted: 2018-06-25 • Accepted: 2019-01-28 • Prepublished online: 2019-04-18 
quality of life of a woman includes a woman's postpartum health condition, as well as the feeling of her well-being and that of her family (Grylka-Bäschlin, 2013).

\section{The methods for the assessment of the quality of life of women in puerperium}

Studies that deal with the measuring of the quality of life of women in puerperium are rather scarce in the Czech Republic (Dušová and Menclová, 2014; Seidlerová and Dušová, 2014; Závodníková, 2015). Researchers often describe reality using quantitative methods and generic tools, such as the questionnaires SF-36, WHOQOL-BREF, MAPP-QOL (Mogos et al., 2013). The WHOQOL-BREF and SF-36 questionnaires have traditionally been used for a long time. A relatively little known questionnaire used in quantitative methodology is the Maternal Postpartum Quality of Life, which was presented by American scientists in 2006 (Hill et al., 2006). So far, it has not been translated into Czech and it has not been used in the Czech Republic.

Very rarely, we can find studies dealing with a mixed approach (quantitative and qualitative methodology) and elements of individualism. Here, we can mention the following example tools for measuring the subjective quality of life of women in puerperium: Schedule for the Evaluation of Individual Quality of Life (SEIQoL) and Mother-Generated Index (MGI). The SEIQoL questionnaire was introduced by J. Křivohlavý in the Czech Republic in 2001 (Vachková et al., 2013). The Mother-Generated Index questionnaire was translated into Czech in 2014 by E. Hendrych Lorenzová, and after the author's approval (Dr. Andrew Symon) it was used in the first research studies (Závodníková, 2015).

The Mother-Generated Index questionnaire is not much known and used in the Czech Republic. For this reason, it will be introduced later.

Table 1. The characteristics of the selected tools for the assessment of the quality of life of women in puerperium according to individual criteria

\begin{tabular}{|c|c|c|c|c|}
\hline $\begin{array}{l}\text { Tool/ } \\
\text { Country of origin }\end{array}$ & $\begin{array}{l}\text { Specific for the } \\
\text { period of puerperium }\end{array}$ & $\begin{array}{l}\text { Number of items/ } \\
\text { Content structure }\end{array}$ & Method of responding & $\begin{array}{c}\text { Type of questionnaire, } \\
\text { methodology }\end{array}$ \\
\hline $\begin{array}{l}\text { SF-36 } \\
\text { Short-Form } 36\end{array}$ & \multirow[t]{2}{*}{ no } & 8 life dimensions & \multirow[t]{2}{*}{ Scaling } & \multirow[t]{2}{*}{$\begin{array}{l}\text { Standardized generic } \\
\text { questionnaire }\end{array}$} \\
\hline $\begin{array}{l}\text { USA (Vad'urová and Mühlpachr, } \\
\text { 2005) }\end{array}$ & & $\begin{array}{l}\text { Physical limitations; } \\
\text { physical pain; general } \\
\text { health; vitality; social } \\
\text { functioning; emotional } \\
\text { problems; mental health }\end{array}$ & & \\
\hline $\begin{array}{l}\text { SEIQoL } \\
\text { Schedule for the Evaluation of }\end{array}$ & \multirow[t]{4}{*}{ no } & 5 life goals & Structured interview & \multirow[t]{4}{*}{$\begin{array}{l}\text { Subjectively perceived } \\
\text { quality of life/interview }\end{array}$} \\
\hline Individual Quality of Life & & & & \\
\hline Ireland & & & & \\
\hline $\begin{array}{l}\text { CZR (Vadurová and Mühlpachr, } \\
\text { 2005) }\end{array}$ & & & $\begin{array}{l}\text { goals from } 0 \text { to } 100 \% \\
\text { regarding all goals. } \\
\text { - The visual analogue } \\
\text { scale of the total life } \\
\text { satisfaction. }\end{array}$ & \\
\hline $\begin{array}{l}\text { WHOQOL-BREF } \\
\text { The World Health Organization } \\
\text { Quality of Life - BREF }\end{array}$ & \multirow[t]{2}{*}{ no } & $\begin{array}{l}24 \text { items in } 4 \text { domains and } \\
2 \text { individual items }\end{array}$ & \multirow[t]{2}{*}{ Scaling } & \multirow[t]{2}{*}{$\begin{array}{l}\text { Standardized generic } \\
\text { questionnaire }\end{array}$} \\
\hline $\begin{array}{l}\text { Switzerland (Vad'urová and } \\
\text { Mühlpachr, 2005) }\end{array}$ & & & & \\
\hline $\begin{array}{l}\text { MAPP-Qol } \\
\text { Maternal postpartum quality } \\
\text { of life }\end{array}$ & \multirow[t]{2}{*}{ yes } & $\begin{array}{c}41 \text { items, } 4 \text { domains: } \\
\text { health, socio-economic, } \\
\text { psychologically-spiritual, } \\
\text { family }\end{array}$ & $\begin{array}{l}2 \text { parts of the } \\
\text { questionnaire, always the } \\
\text { Likert scale: } \\
\text { 1. Assessment }\end{array}$ & \multirow[t]{2}{*}{$\begin{array}{l}\text { Standardized generic } \\
\text { questionnaire }\end{array}$} \\
\hline USA (Hill et al., 2006) & & & $\begin{array}{l}\text { of satisfaction - } \\
\text { dissatisfaction with an area } \\
\text { of life. } \\
\text { 2. Establishment of the } \\
\text { importance of a life event. }\end{array}$ & \\
\hline $\begin{array}{l}\text { PNMI } \\
\text { Postnatal Morbidity Index } \\
\text { Great Britain (Symon et al., } \\
\text { 2003b) }\end{array}$ & yes & $\begin{array}{l}3 \text { monitored domains: } \\
\text { a woman's physical } \\
\text { morbidity; children's } \\
\text { physical morbidity; a } \\
\text { mother's relationship to } \\
\text { her child }\end{array}$ & $\begin{array}{l}\text { Questionnaire with the } \\
\text { following items: type } \\
\text { of postpartum injury; } \\
\text { the treatment of the } \\
\text { injury; the number of } \\
\text { re-hospitalizations and its } \\
\text { causes }\end{array}$ & $\begin{array}{l}\text { Standardized generic } \\
\text { questionnaire }\end{array}$ \\
\hline
\end{tabular}


Table 1. (Continued)

\begin{tabular}{|c|c|c|c|c|}
\hline $\begin{array}{l}\text { Tool/ } \\
\text { Country of origin }\end{array}$ & $\begin{array}{l}\text { Specific for the } \\
\text { period of puerperium }\end{array}$ & $\begin{array}{l}\text { Number of items/ } \\
\text { Content structure }\end{array}$ & Method of responding & $\begin{array}{l}\text { Type of questionnaire, } \\
\text { methodology }\end{array}$ \\
\hline $\begin{array}{l}\text { MAMA } \\
\text { Maternal Adjustments and }\end{array}$ & yes & 60 questionnaire items & Scaling & $\begin{array}{l}\text { Standardized generic } \\
\text { questionnaire }\end{array}$ \\
\hline $\begin{array}{l}\text { Maternal Attitude } \\
\text { Great Britain (Symon et al., } \\
\text { 2003b) }\end{array}$ & & $\begin{array}{l}5 \text { subscales: } \\
\text { body appearance; physical } \\
\text { symptoms; sexuality, } \\
\text { relationship with the } \\
\text { child; relationship with the } \\
\text { partner }\end{array}$ & & $\begin{array}{l}\text { Questionnaire filled in by } \\
\text { the respondent themselves }\end{array}$ \\
\hline $\begin{array}{l}\text { MGI } \\
\text { Mother-Generated Index }\end{array}$ & yes & $\begin{array}{c}\text { A maximum of } 8 \text { life areas, } \\
\text { no domains, only examples } \\
\text { of responses }\end{array}$ & $\begin{array}{l}\text { Mixed questionnaire with } \\
\text { elements of individualism }\end{array}$ & $\begin{array}{l}\text { Subjectively perceived } \\
\text { quality of life/interview }\end{array}$ \\
\hline $\begin{array}{l}\text { Great Britain (Scotland) (Symon } \\
\text { et al., 2003b) }\end{array}$ & & Responses by respondents & $\begin{array}{c}3 \text { degrees of responses } \\
\text { (assessment }- \text { scaling } \\
\text { - considering the } \\
\text { importance) }\end{array}$ & $\begin{array}{l}\text { Model "one-to-one" - } \\
\text { respondent + administrator }\end{array}$ \\
\hline
\end{tabular}

\section{The origin of the Mother-Generated Index questionnaire}

The Mother-Generated Index is a questionnaire with a mixed approach (quantitative and qualitative methodology) and elements of individualism. Its author is Dr. Andrew Symon, a lecturer in midwifery at the University of Dundee in Scotland. The Mother-Generated Index questionnaire is a tool which subjectively measures the perceived postpartum quality of life, but it can be used in late pregnancy. This questionnaire was used in a number of cultural contexts (Symon et al., 2003a).

The questionnaire is based on the original tool for measuring the quality of life - Patient-Generated Index. This questionnaire was used in a pilot research study which was published in 2003 (Symon et al., 2003a).

\section{The specifics and the focus of the questionnaire}

The presented Mother-Generated Index questionnaire is based on Calman's definition of the perception of the quality of life, which suggests that the quality of life measures the difference, or the gap, at a particular period of time between the hopes and expectations of the individual and that individual's present experiences (Grylka-Bäschlin, 2013). At the beginning, this subjectively perceived quality of life was criticized for being unspecific regarding the assessment of life areas or a large variety of responses, which may cause a difficult mutual assessment. On the other hand, to provide a sensitive and individual description of the perception of the subjective quality of life (specifically, women in puerperium), we need a tool which will provide information about the importance of the perception of women's health regarding their life (Grylka-Bäschlin, 2013).

The questionnaire is divided into three steps. First, a respondent should identify up to eight life areas which suffered the largest impact after the birth of her child. After that, she should say whether the change is positive, negative or both. The perception of life is very individual. We showed some examples, such as the relationship with her partner, harmoniousness with the role of a mother or the relationship towards herself. Second, the respondent should use the scale of numbers, where 0 is the worst possible and 10 is the best possible, to assess the given life areas in the last month. Third, the respondent marks the importance of the changes in the given life areas. There are a maximum of 20 points, which she can give according to the importance of changes in the individual life areas. More points mean greater importance. However, they are not obliged to give points to every life area, so all 20 points do not have to be used (Symon et al., 2003b).

\section{The pilot study and the validation of the questionnaire}

The pilot study on the use of the MGI questionnaire was published in the Journal of Advanced Nursing in 2003. Its methodology is better described in Table 2. The conclusion of this study confirms that the use of this questionnaire in practice is satisfying. It helps women in puerperium to identify the main life areas that are most dissatisfying or satisfying. Medical workers are then able to understand the woman better and to work with her individually (Symon et al., 2003a).

The questionnaire was validated again in 2003. The goal of the validation was the assessment of the correlation of the questionnaire with the established measuring tools, which were: Postnatal Morbidity Index (PNMI), Maternal Adjustment and Maternal Attitudes (MAMA), EPDS (Edinburgh Postnatal Depression Scale). The MGI questionnaire counts the so-called index of the quality of life of women in puerperium. It is counted by adding all of the points in the second step (on the scale from 0 to 10) and dividing them by the number of items (a maximum of 8 , as mentioned in the first step). The result is the average of the given values on the scale and the personal index of the quality of life of a woman in puerperium.

The results of the test correlation showed that women with a total index score of 5 or less experienced a higher incidence of physical problems, a higher EPDS score and a lower MAMA score. The MGI questionnaire was then recognized as a valid tool for the assessment of the quality of life of women (Symon et al., 2003b).

\section{The use of the questionnaire in other countries and the Czech Republic}

The MGI questionnaire has been used in several foreign countries: India, China, Brazil, Iran, Portugal, Poland, Germany, Great Britain (Symon et al., 2013).

The MGI questionnaire was translated into Czech by E. Hendrych Lorenzová in 2014 and was first used in practice in the Bachelor's degree thesis of Dana Závodníková (2015). It is possible to use the Czech version after the author's approval. 


\section{Materials and methods}

The main goal of this study was to use relevant data from licensed and free available internet databases and present the Mother-Generated Index questionnaire, its formation, significance, specification, validation and available results. We asked the following clinical question of the "background" type: "What specialist information was published regarding the Mother-Generated Index questionnaire?"

The sources were searched for in full-text electronic databases. We used the method of content document analysis. The used documents were found in the following scientific databases: EBSCOhost, Science Direct, Pro Quest, Nursing Ovid, Google Scholar, PubMed, Scopus. The search and the processing of available studies were carried out between February and April 2018. The keywords were: Quality of life after childbirth, Mother-Generated Index, Midwifery Community Care, and the Boole operator "and", which helps to find the terms used together. We always used the term Mother-Generated Index and another keyword or their combination. We only included studies in English or Czech; the time period was not important (the questionnaire was launched in 2003).

The first phase of the search for relevant data included 81 studies. We excluded duplicate studies, studies that did not deal with the topic in the necessary context, and studies that were not available in full text. We finally used 8 studies (Diagram 1). The data analysis included one randomized controlled study.

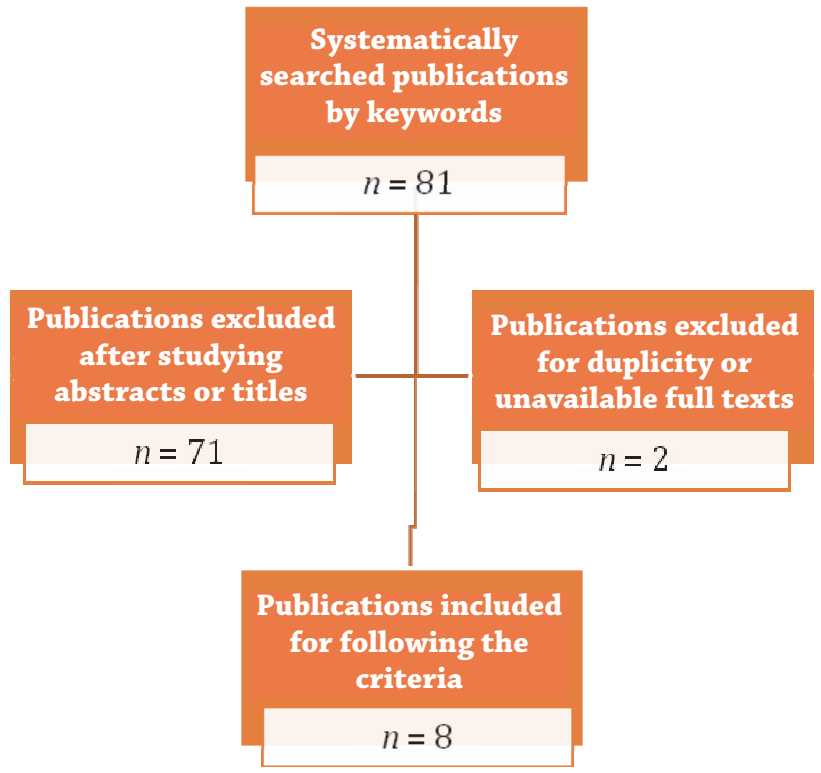

Diagram 1. Diagram of the included studies

\section{Results}

Table 2. Included studies which deal with the Mother-Generated Index questionnaire regarding the quality of life of women in puerperium

\begin{tabular}{|c|c|c|c|c|c|}
\hline $\begin{array}{l}\text { Author/ } \\
\text { Year of publishing }\end{array}$ & $\begin{array}{c}\text { Country of } \\
\text { origin }\end{array}$ & Goal & Methodology & $\begin{array}{l}\text { Research group/ } \\
\text { Other included } \\
\text { questionnaires }\end{array}$ & Main finding \\
\hline $\begin{array}{l}\text { Symon et al. } \\
\text { (2003a) }\end{array}$ & $\begin{array}{c}\text { Great } \\
\text { Britain } \\
\text { (Scotland) }\end{array}$ & $\begin{array}{l}\text { 1. To assess the level of } \\
\text { correlation of the MGI } \\
\text { questionnaire with the } \\
\text { existing tools } \\
\text { 2. To compare the life } \\
\text { areas of women in } \\
\text { puerperium, which } \\
\text { affect the perception } \\
\text { of the quality of life } \\
\text { and describe their } \\
\text { significance }\end{array}$ & $\begin{array}{l}\text { Face-to-face interviews } \\
\text { from June } 2000 \text { to March } \\
\text { 2001. The interviews were } \\
\text { carried out by } 4 \text { medical } \\
\text { workers } \\
\text { The interviews were } \\
\text { carried out in the 6th to } \\
\text { 8th week after childbirth } \\
\text { and the 8th month after } \\
\text { childbirth }\end{array}$ & $\begin{array}{l}103 \text { women after } \\
\text { childbirth } \\
\text { EPDS, } \\
\text { SF-12 }\end{array}$ & $\begin{array}{c}\text { MGI helps women to identify } \\
\text { the most disturbing areas } \\
\text { of life }\end{array}$ \\
\hline $\begin{array}{l}\text { Symon et al. } \\
\text { (2003b) }\end{array}$ & $\begin{array}{c}\text { Great } \\
\text { Britain } \\
\text { (Scotland) }\end{array}$ & $\begin{array}{c}\text { Validation of the MGI } \\
\text { questionnaire }\end{array}$ & $\begin{array}{l}\text { The assessment of } \\
\text { the correlation of the } \\
\text { questionnaire with the } \\
\text { established measuring } \\
\text { tools }\end{array}$ & $\begin{array}{l}\text { A total of } 102 \text { after } \\
\text { childbirth. } 51 \text { in the } \\
\text { period of } 6-8 \text { weeks } \\
\text { after childbirth and } \\
51 \text { in the period of } \\
6-8 \text { months after } \\
\text { childbirth. } \\
\text { Postnatal Morbidity } \\
\text { Index (PNMI), } \\
\text { Maternal Adjustment } \\
\text { and Maternal } \\
\text { Attitudes (MAMA), } \\
\text { EPDS (Edinburgh } \\
\text { Postnatal Depression } \\
\text { Scale) }\end{array}$ & $\begin{array}{l}\text { The testing of the MGI } \\
\text { questionnaire proved its } \\
\text { validity in measuring the } \\
\text { postpartum quality of life of } \\
\text { women (in both monitored } \\
\text { time periods after childbirth) } \\
\text { Very frequent postpartum } \\
\text { quality of life areas were } \\
\text { psychological and social } \\
\text { changes, the positive } \\
\text { relationship with the child. } \\
\text { Physical changes after } \\
\text { childbirth were commented } \\
\text { on very little. }\end{array}$ \\
\hline
\end{tabular}


Table 2. (Continued)

\begin{tabular}{|c|c|c|c|c|c|}
\hline $\begin{array}{l}\text { Author/ } \\
\text { Year of publishing }\end{array}$ & $\begin{array}{c}\text { Country of } \\
\text { origin }\end{array}$ & Goal & Methodology & $\begin{array}{l}\text { Research group/ } \\
\text { Other included } \\
\text { questionnaires }\end{array}$ & Main finding \\
\hline & & & & & $\begin{array}{l}\text { Women with the total score } \\
\text { of index } 5 \text { or less had a } \\
\text { significantly higher incidence } \\
\text { of physical problems; higher } \\
\text { EPDS score and lower MAMA } \\
\text { score }\end{array}$ \\
\hline \multirow[t]{2}{*}{ Nagpal et al. (2008) } & \multirow[t]{2}{*}{ India } & \multirow[t]{2}{*}{$\begin{array}{l}\text { To assess the usefulness } \\
\text { of the MGI questionnaire } \\
\text { regarding the description } \\
\text { of the quality of life of } \\
\text { women after childbirth } \\
\text { in India }\end{array}$} & \multirow[t]{2}{*}{ Semi-structured interviews } & \multirow[t]{2}{*}{$\begin{array}{l}\text { A total of } 195 \text { women } \\
\text { up to } 6 \text { months after } \\
\text { childbirth, randomly } \\
\text { divided into two } \\
\text { groups. A total of } \\
94 \text { women were } \\
\text { instructed in English } \\
\text { and } 101 \text { in Hindu } \\
\text { EPDS }\end{array}$} & $\begin{array}{l}\text { The MGI questionnaire is } \\
\text { possible to be considered as } \\
\text { a valid tool that maps the } \\
\text { postpartum quality of life of } \\
\text { women } \\
\text { There were no significant } \\
\text { differences between the MGI } \\
\text { index in women with Hindu } \\
\text { and English }\end{array}$ \\
\hline & & & & & $\begin{array}{l}\text { The disadvantage of } \\
\text { the questionnaire is the } \\
\text { impossibility of comparing } \\
\text { the responses with another } \\
\text { questionnaire }\end{array}$ \\
\hline Symon et al. (2013) & $\begin{array}{l}\text { Great } \\
\text { Britain } \\
\text { (Scotland), } \\
\text { India, } \\
\text { Poland, } \\
\text { Iran, } \\
\text { Portugal, } \\
\text { Brazil, } \\
\text { China }\end{array}$ & $\begin{array}{l}\text { 1. To study problems } \\
\text { and solutions regarding } \\
\text { the translation of } \\
\text { the questionnaire } \\
\text { into English, Hindu, } \\
\text { Mandarin, Persian, } \\
\text { Portuguese, Polish and } \\
\text { Brazilian Portuguese } \\
\text { 2. Options of using the } \\
\text { MGI questionnaire in } \\
\text { countries with different } \\
\text { cultures }\end{array}$ & $\begin{array}{l}\text { 1. The analysis of } \\
\text { individual intercultural } \\
\text { studies. A more specific } \\
\text { focus on unique elements } \\
\text { in the perception of } \\
\text { the quality of life of } \\
\text { women after childbirth, } \\
\text { experiences of new } \\
\text { mothers with motherhood. } \\
\text { 2. The studies were also } \\
\text { assessed from the point } \\
\text { of view of cultural and } \\
\text { philosophical differences } \\
\text { which can cause the MGI } \\
\text { tool to be inapplicable } \\
\text { although it was translated } \\
\text { very well }\end{array}$ & $\begin{array}{l}6 \text { individual post } \\
\text { graduate scientific } \\
\text { studies on the level } \\
\text { of national research. } \\
\text { Two of them were } \\
\text { published before they } \\
\text { were included in a } \\
\text { scientific journal. }\end{array}$ & \\
\hline Khabiriet al. (2013) & Iran & $\begin{array}{l}\text { Validation of the MGI } \\
\text { in Iran }\end{array}$ & Face-to-face interviews & $\begin{array}{l}124 \text { after childbirth } \\
\text { (the time period is not } \\
\text { specified) }\end{array}$ & $\begin{array}{l}\text { The MGI was assessed as a } \\
\text { valid tool for measuring the } \\
\text { quality of life of women after } \\
\text { childbirth }\end{array}$ \\
\hline $\begin{array}{l}\text { Grylka-Bäschlin et } \\
\text { al. (2015) }\end{array}$ & Germany & $\begin{array}{l}\text { Validation of the MGI in } \\
\text { Germany }\end{array}$ & & $\begin{array}{l}\text { HADS (Hospital } \\
\text { Anxiety and } \\
\text { Depression Scale), } \\
\text { PNMI (Postnatal } \\
\text { Morbidity Index) }\end{array}$ & $\begin{array}{l}\text { The MGI was assessed as a } \\
\text { valid tool for measuring the } \\
\text { quality of life of women after } \\
\text { childbirth. A higher quality } \\
\text { of life (index) is directly } \\
\text { related to a lower incidence of } \\
\text { depression and anxiety } \\
(p<0.01) \text {. }\end{array}$ \\
\hline Ribeiro et al. (2015) & Brazil & $\begin{array}{l}\text { Translation of MGI into } \\
\text { Brazilian Portuguese } \\
\text { The description of the } \\
\text { use of the questionnaire } \\
\text { across the diverse } \\
\text { cultural Brazilian } \\
\text { environment }\end{array}$ & Semi-structured interviews & $\begin{array}{l}30 \text { women after } \\
\text { childbirth; the } \\
\text { interviews were carried } \\
\text { out approximately } 30 \\
\text { days after childbirth }\end{array}$ & $\begin{array}{l}\text { The questionnaire was valid } \\
\text { for the assessment of the } \\
\text { quality of life of women after } \\
\text { childbirth in Brazil. The MGI } \\
\text { is recommended for use in } \\
\text { healthcare. }\end{array}$ \\
\hline
\end{tabular}


Table 2. (Continued)

\begin{tabular}{|c|c|c|c|c|c|}
\hline $\begin{array}{l}\text { Author/ } \\
\text { Year of publishing }\end{array}$ & $\begin{array}{l}\text { Country of } \\
\text { origin }\end{array}$ & Goal & Methodology & $\begin{array}{l}\text { Research group/ } \\
\text { Other included } \\
\text { questionnaires }\end{array}$ & Main finding \\
\hline Symon et al. (2015) & $\begin{array}{c}\text { Great } \\
\text { Britain }\end{array}$ & $\begin{array}{l}\text { The assessment of } \\
\text { performability and } \\
\text { acceptability of the } \\
\text { MGI in a randomized } \\
\text { controlled study } \\
\text { Comparison of } \\
\text { the results of the } \\
\text { measured quality of } \\
\text { life to commonly used } \\
\text { measuring tools }\end{array}$ & $\begin{array}{l}\text { Randomized controlled } \\
\text { study } \\
\text { Women included in the } \\
\text { study received a 10-page } \\
\text { questionnaire set and the } \\
\text { last page was the MGI }\end{array}$ & $\begin{array}{l}400 \text { women after } \\
\text { childbirth, the end of } \\
\text { puerperium } \\
\text { EPDS (Edinburgh } \\
\text { Postnatal Depression } \\
\text { Scale), SWLS } \\
\text { (Satisfaction With } \\
\text { Life Scale), STAI } \\
\text { (State Trait Anxiety } \\
\text { Inventory), EQ-5D-3 L } \\
\text { (EuroQol 5D) }\end{array}$ & $\begin{array}{l}\text { Despite the fact that all } \\
\text { compared questionnaires } \\
\text { proved a low level of } \\
\text { correlation with the MGI } \\
\text { ( } p<0.1) \text {, the MGI was } \\
\text { accepted as a valid tool } \\
\text { for the assessment of the } \\
\text { quality of life of women after } \\
\text { childbirth } \\
\text { According to the authors, } \\
\text { the low correlation of the } \\
\text { questionnaire is probably } \\
\text { caused by the impossibility } \\
\text { of comparing the responses } \\
\text { of the respondents because } \\
\text { individual responses are } \\
\text { required here } \\
\text { The questionnaire combines } \\
\text { the power of a qualitative and } \\
\text { quantitative questionnaire. } \\
\text { It is not administratively and } \\
\text { financially demanding. It is } \\
\text { easy to translate into a wide } \\
\text { cultural and lingual context. }\end{array}$ \\
\hline
\end{tabular}

\section{Discussion}

The Mother-Generated Index questionnaire is focused on the assessment of the subjective quality of life of women after childbirth, which makes it original and specific. Despite its great contribution, it is sometimes criticized. The main argument is that the subjective quality of life of a woman after childbirth is difficult to compare to other tools (Hill et al., 2006). This is partially recognized by the author himself, Dr. Symon (Vachková et al., 2013). On the other hand, he also states that the power of the questionnaire is in its subjective approach. There are also a few available questionnaires that are focused on the assessment of the mentioned items or aimed at physical morbidity or postpartum depression. Here, medical workers did not have a specific measuring tool that would describe the feeling of well-being in puerperium. This cannot do without a subjective perception of reality. The quality of life is considered an individual perception to such an extent that there is no way for it to be placed into pre-prepared categories or universally understood (Symon et al., 2003b).

The existing use of the MGI questionnaire in several foreign countries has shown its trans-cultural utilizability and comprehensibility' although the authors have recorded that the concept of the quality of life can be perceived differently in every country.

Countries where the MGI questionnaire was used (Symon et al., 2013):

- India - the MGI tool presented many conceptual and practical difficulties regarding the use in different cultural environments. The researcher must pay attention to the excellent translation of the questionnaire as well as the exact definition of the locality of the research and included par- ticipants. It is crucial to sensitively explain the term "the quality of life". Some cultures do not understand this term. This term (the quality of life) was rarely understood even in educated society. It can present a potential constructive bias. The socio-cultural differences in this environment are extreme even in small localities. It was helpful to ask about postpartum morbidity so that the term "the quality of life" would be understood.

- China - the respondents often failed to understand what to state. They were not used to being asked about their feelings. Another significant factor was that women mostly had one child. They often said that they did not have anything to compare their experiences with.

- Poland - pregnancy, childbirth and motherhood are considered positive periods in a woman's life. If a woman states some negative connotations, she might be considered a bad mother.

- Portugal - The term "quality of life" was well understood by the respondents.

- Brazil - different cultural environments affected the understanding of "the postpartum quality of life". Women often needed to be assured that they had answered correctly, e.g. "Did I say it right?" or "Is this the answer you want?" Nevertheless, in total, the concept of the term "the quality of life" was well understood. However, the respondents did not understand how to assign the points regarding life areas that they mentioned. Finally, beans (regional aliment) served as an aid. The respondents had 20 white beans that they assigned to individual items and the record-keeper recorded the final score (Ribeiro et al., 2015).

- Iran - understanding the term "the quality of life" was not a problem. The respondents easily spoke of negative aspects of motherhood including changes in the socio-economic situation (Khabiri et al., 2013). 
Other possible limitations of this questionnaire can include the average time for filling it in, which is approximately 30 minutes (including the instructions given by a medical worker). The questionnaire also does not study the level of support given to mothers after childbirth in the socio-economic context (Symon et al., 2003b).

\section{Conclusions}

Despite the mentioned limitations, this questionnaire can be considered as a very valuable and sensitive tool which shows the quality of life of women after childbirth. Medical workers need the fullest information about women available so that they can work with them holistically. The Mother-Generated Index questionnaire seems to be a suitable tool.

The studied articles recommend more publications on emotional changes during motherhood. They also recommend carrying out more qualitative researches which would not focus only on the informative structure of literature and information about man that is rather normative. Let us not be afraid to step onto live, changeable and dynamic ground which offers more detailed experiences.

We would like to conclude with a comment that in the Czech Republic, midwives' community care of women after childbirth is still broadly unavailable. It is as if medical workers have been searching for the absence of illnesses and not a broader conception of health regarding well-being. In such a sensitive period (a woman's transformation into a mother), it is necessary to support and contact her continuously. The MGI questionnaire could be a contribution and a help to community midwives who provide care to women after childbirth.

\section{Conflict of interests}

The authors have no conflict of interests to declare.

\section{Acknowledgements}

The authors would like to thank Dr. Andrew Symon, who has always been very willing to communicate and provide information regarding the Mother-Generated Index questionnaire. We are still in contact with the author of the questionnaire, who is continuously informed about the first results of the use of the MGI in the Czech Republic.

\section{Kvalita života ženy v poporodním období - představení dotazníku Mother-Generated Index (MGI)}

\section{Souhrn}

Poporodní období představuje kritický a transformační úsek života pro každou ženu, novorozence i novou rodinu, a to na úrovni fyzické, psychické i sociální.

Desing: Popisná přehledová studie.

Cíl: Cílem tohoto příspěvku je blíže představit dotazník Mother-Generated Index, který by mohl být využíván v komunitní praxi porodních asistentek při péči o ženy po porodu.

Metodika: Pro zpracování této přehledové studie byla použita metoda obsahové analýzy dokumentů. Dokumenty byly vyhledávány ve vědeckých databázích EBSCOhost, Science Direct, Pro Quest, Nursing Ovid, Google Scholar, PubMed, Scopus. Vyhledávání a zpracování dostupných studií probíhalo od února do dubna 2018. V konečném výběru bylo identifikováno osm studií, které vyhovují stanoveným kritériím.

Závěr: Dotazník Mother-Generated Index byl prokázán jako validní nástroj popisující subjektivně vnímanou kvalitu života ženy po porodu smíšenými metodami. Je možné ho využít i v transkulturním prostředí. Dotazník byl do českého jazyka přeložen v roce 2014, výzkumné závěry jeho použití u žen po porodu zatím čekají na svoje zveřejnění.

Klíčová slova: kvalita života po porodu; komunitní péče porodní asistentky; mateřství; Mother-Generated Index; porodní asistence

\section{References}

1. Antonowsky A (1996). The salutogenic model as a theory to guide health promotion. Health Promot Int 11(1): 11-18. DOI: 10.1093/heapro/11.1.11.

2. Baloun I, Velemínský M (2018). Validizované dotazníky PedsQL pro hodnocení kvality života u dětí a jejich rodin. Kontakt 20(2): 168-174.

3. Bašková M, Urbanová E, Maskálová E (2011). Postpartum Care in Slovakia in European Context. Journal of Nursing, Social Studies and Public Health 2(1-2): 23-27.

4. Coyle KL, Hauck Y, Percival P, Kristjanson LJ (2001). Normality and collaboration: mothers' perceptions of birth centre versus hospital care. Midwifery 17(3): 182-193. DOI: 10.1054/ midw.2001.0256

5. Dušová B. Menclová A (2014). Kvalita života ženy po spontánním a operativním porodu. Florence 10(12): 18-19.

6. Grylka-Bäschlin S (2013). Application of the Mother-Generated Index to German-speaking women for the assessment of cultural differences in postnatal quality of life. Master Thesis. Hannover Medical School.

7. Grylka-Bäschlin S, van Teijlingen E, Stoll K, Gross MM (2015). Translation and validation of the German version of the Mother-Generated Index and its application during the postnatal period. Midwifery 31(1): 47-53. DOI: 10.1016/j. midw.2014.05.002.

8. Gurková E (2011). Hodnocení kvality života: pro klinickou praxi a ošetřovatelský výzkum. Praha: Grada, 15 p.

9. Hill PD, Aldag JC, Hekel B, Riner G, Bloomfield P (2006). Maternal postpartum quality of life questionnaire. J Nurs Meas 14(3): 205-220. DOI: 10.1891/jnm-v14i3a005.

10. Khabiri R, Rashidian A, Montazeri A, Symon A, Foroushani AR, Arab M, Rashidi BH (2013). Validation of the Mother-Generated Index in Iran: A specific postnatal quality-of-life instrument. Int J Prev Med 4(12): 1371-1379.

11. Mogos MF, August EM, Salinas-Miranda AA, Sultan DH, Salihu HM (2013). A systematic review of quality of life measures in pregnant and postpartum mothers. Appl Res Qual Life 8(2): 219-250. 
12. Nagpal J, Dhar RS, Sinha S, Bhargava V, Sachdeva A, Bhartia A (2008). An exploratory study to evaluate the utility of an adapted Mother-Generated Index (MGI) in assassment of postpartum quality of life in India. Health and Qual Life Outcomes 6(107): 100-110. DOI: 10.1186/1477-7525-6-107.

13. Ribeiro SG, Symon AG, Lessa PR, de Oliveira MF, Aquino Pde S, de Almeida PC, Pinheiro AK (2015). Translation and cultural adaptaton of the Mother-Generated Index into Brazilian Portuguese: A postnatal quality of life study. Midwifery 31(7): 735-741. DOI: 10.1016/j.midw.2015.03.009.

14. Seidlerová J, Dušová B (2014). Kvalita života u žen po spontánním porodu a císařském řezu. Zdravotnictví a medicína 2014(19): 11.

15. Symon, A, Downe, S, Finlayson KW, Knapp R, Diggle P, SHIP trial team (2015). The feasibility and acceptability of using the Mother-Generated Index (MGI) as a Patient Reported Outcome Measure in a randomised controlled trial of maternity care. BMC Med Res Methodol 15: 100. DOI: 10.1186/s12874-0150092-0.

16. Symon A, MacKay A, Ruta D (2003a). Postnatal quality of life: a pilot study using the Mother-Generated Index. J Adv Nurs 42(1): 21-29. DOI: 10.1046/j.1365-2648.2003.02575.x.
17. Symon A, McGreavey J, Picken C (2003b). Postnatal quality of life assessment: validation of the Mother-Generated Index. BJOG 110(9): 865-868. DOI: 10.1111/j.14710528.2003.02030.x

18. Symon A, Nagpal J, Maniecka-Bryła I, Nowakowska-Głąb A, Rashidian A, Khabiri R (2013). Cross-cultural adaptation and translation of a quality of life tool for new mothers: a methodological and experiential account from six countries. J Adv Nurs 69(4): 970-980. DOI: 10.1111/j.13652648.2012.06098.x.

19. Vachková E, Čermáková E, Mareš J (2013). Kvalita života žen v období mateřství pomocí metody SEIQOL. Ošetřovatelství a porodní asistence 4(2): 595-599.

20. Vad'urová H, Mühlpachr P (2005). Kvalita života: teoretická a metodologická východiska. Brno: Masarykova univerzita v Brně, pp. 11-17.

21. Závodníková D (2015). Kvalita života ženy v období mateřství. Bakalářská práce. Hradec Králové: UK v Praze, Lékařská fakulta v Hradci Králové. 